\title{
Effect of applying Bacillus-based products on the production of strawberry cultivars
}

\author{
Csaignon Mariano Caproni ${ }^{1}$, Renata Alves Lara Silva Rezende ${ }^{2}$, Filipe Almendagna Rodrigues ${ }^{2}$, Moacir \\ Pasqual $^{2}$ \\ ${ }^{1}$ Empresa de Pesquisa Agropecuária de Minas Gerais - EPAMIG, Pouso Alegre, MG. ${ }^{2}$ Universidade Federal de Lavras - \\ UFLA, Lavras, MG. E-mail: renata_vga@yahoo.com.br
}

\begin{abstract}
One of the factors that can compromise the strawberry culture is the use of seedlings without phytosanitary quality. The aim of this study was to evaluate the use of three biological products in the production of strawberry cultivars. For this, six cultivars ('Camino Real', 'Festival', 'Oso Grande', 'Albion', 'San Andreas' and 'Camarosa') were selected to receive the following treatments: T1) Onix (2.4 mL) + Qualit (0.6 mL) (Bacillus methylotrophicus + Trichoderma asperellum); T2) Rhizos (2.4 mL) + Qualit (0.6 mL) (Bacillus subtilis + Trichoderma asperellum) and T3) Control. After the production cycle, the total production $\left(\mathrm{g} \mathrm{kg}^{-1}\right)$, estimated average production $\left(\mathrm{kg} \mathrm{ha}^{-1}\right)$ and number of fruits in each plot were evaluated. 'Festival' and 'Oso Grande' were the most productive cultivars and their greatest yields were observed in the presence of Bacillus compared to control. Plants grown in the presence of $B$. methylotrophicus and $B$. subtilis showed a higher number of fruits. The use of these biological products is important for strawberry cultivation.
\end{abstract}

Keywords: bacteria; beneficial microorganisms; biological control; Fragaria x Ananassa.

\section{Efeito da aplicação de produtos à base de Bacillus na produção de cultivares de morangueiro}

\section{Resumo}

Dentre os fatores que podem comprometer a cultura do morangueiro destaca-se a utilização de mudas sem qualidade fitossanitária. O objetivo desse estudo foi avaliar a utilização de três produtos biológicos na produção de cultivares de morango. Para isso, seis cultivares ('Camino Real', 'Festival', 'Oso Grande', 'Albion', 'San Andreas' e 'Camarosa') receberam os seguintes tratamentos: T1) Onix (2,4 mL) + Qualit (0,6 $\mathrm{mL}$ ) (Bacillus methylotroficos + Trichoderma asperellum); T2) Rizos $(2,4 \mathrm{~mL})+$ Qualit $(0,6 \mathrm{~mL})$ (Bacillus subtilis $+T$. asperellum) e T3) Controle. Após o ciclo de produção foram avaliadas a produção total ( $\mathrm{kg} \mathrm{ha}^{-1}$ ) e o número de frutos em cada parcela. As cultivares 'Festival' e 'Oso Grande' foram as mais produtivas e suas maiores produções foram observadas na presença dos Bacillus em relação ao controle. Plantas cultivadas na presença de $B$. methylotrophicus e $B$. subtilis apresentaram maior número de frutos. $O$ emprego desses produtos biológicos mostra-se importante para a cultura do morango.

Palavras-chave: bactérias; controle biológico; Fragaria x Ananassa; microrganismos benéficos.

\section{Introduction}

The use of microorganisms that provide some beneficial effect on plants has been considered a new strategy to improve plant growth in a sustainable way (SOUSA et al., 2019). Plant growth-promoting bacteria (PGPB) can be used as an alternative to the application of fertilizers on plants, except as leguminous plants, intending higher yields (DADRASNIA et al., 2020). Among these microorganisms, the rhizobacteria play important roles as fertilizers and plant biological stimulants through the production of hormones (indolacetic acid, gibberellin, cytokine and ethylene), by dissolving minerals, and 
indirectly preventing the attack of pathogenic microorganisms (WIDNYANA et al., 2019). The BPCV of the genus Bacillus is one of the most researched (CHOUDHARY; JOHRI, 2009), standing out as $B$. subtilis and $B$. methylotrophicus species that are exhibited in the rhizosphere and have shown actions against pathogens and as promoters of plant growth (LANNA FILHO et al., 2010; BRAGA JUNIOR et al., 2017; FERREIRA, 2019).

Strawberry (Fragaria $x$ Ananassa) is an important vegetable crop in Brazil. However, its crops are dispersed in few regions of the country, totaling around 4 thousand ha of planted area, where the South of Minas Gerais stands out as the largest producing region (PALOMBINI, 2019). The cultivation is carried out mainly by small and medium producers (CERUTTI; SANTOS, 2018) since it is a culture with higher costs, making it difficult to employ a large number of people in the fields.

Among the various factors inherent in strawberry production, the use of quality seedlings is a key factor. The use of low quality seedlings can impact on all stages after planting, causing losses to the producer. Regardless of the production system adopted, the use of good seedlings will favor the best setting, initial development of the plant and, consequently, better production (GONÇALVES; ANTUNES, 2018). In addition, the use of quality seedlings implies less need for applications of substances to control diseases and pests. The conventional system with the use of agrochemicals is still the main form of production in the crop and it is estimated that only $1 \%$ of the cultivated area in the country is destined for organic production (TONIN et al., 2017; DAROLT, 2008).

Currently, sustainable strawberry production has been growing due to the increased demand for healthy food by consumers (CAPRONI et al., 2013). For this reason, there is a need to carry out an appropriate management to increase the performance and quality of the fruits in a sustainable way.

Given the above, this study aimed at evaluating the effect of using biological products as a way to increase production in strawberry cultivars grown in the South of Minas Gerais state.

\section{Material and Methods}

The experiment was carried out in Pouso Alegre, South of Minas Gerais, a municipality located at an average altitude of $1100 \mathrm{~m}$ and with climatic classification of the Cwa type with dry winter and rainy summer, according to Köppen. The average annual temperature is $19.2{ }^{\circ} \mathrm{C}$ with a relative humidity of $75 \%$ and annual precipitation around $1744 \mathrm{~mm}$.

Seedbeds of $1.20 \mathrm{~m} \times 0.25 \mathrm{~m}$ were prepared approximately 30 days before planting. Organic compost $\left(10 \mathrm{~L} \mathrm{~m}^{-2}\right)$ and lime $\left(2.0 \mathrm{t} \mathrm{ha}^{-1}\right)$ were applied to the seedbeds and incorporated with the aid of a rotary hoe. A mulching system was used as soon as the seedlings were stablished. Different combinations of three biological products were applied (Onix, Qualit, and Rizos) that contained isolates of Bacillus subtilis, Bacillus methylotroficus and Trichoderma asperellum in six strawberry cultivars (Camino Real, Festival, Oso Grande, Albion, San Andreas and Camarosa).

The experiment was conducted in a randomized block design, with 18 treatments and three replicates, totaling 54 plots. Each plot occupied an area of $0.72 \mathrm{~m}^{2}$, spaced $0.30 \times 0.30$ $\mathrm{m}$, with four planting lines. The treatments were composed as described below: T1) Onix (2.4 mL) + Qualit (0.6 mL) (B. methylotrophics + Trichoderma asperellum); T2) Rhizos (2.4 mL) + Qualit $(0.6 \mathrm{~mL})$ (B. subtilis + Trichoderma asperellum) and T3) Control (water only).

The products were applied every 15 days after planting the seedlings, during the entire production cycle (seven months).

The drip irrigation system was adopted. It allowed the watering of the plants simultaneously with the use of organic fertigation in coverage. All cultural treatments were carried out, as well as fertilization for the crop. In drip fertigation, applications of the commercial products Megafol $^{\circledR}$ and Organic $^{\circledR}$ were made, at fortnightly intervals, to promote root growth. Still covered in fertigation, the formulated NPK 13-4013 was used, diluted in water and applied monthly.

The harvest of the first ripe fruits started in the second half of June and was completed at the end of October, with a 4-month cycle of table fruit production in 2017. Total production (g) and number of fruits in each plot were evaluated.

The data obtained were subjected to analysis of variance and, in case of significance, the means were compared by the Tukey test $(P \leq 0.05)$ using the statistical software SISVAR (FERREIRA, 2011). 


\section{Results and Discussion}

A significant interaction was observed between the application of biological products and strawberry cultivars for total fruit production (Table 1).

Table 1. Total production (g) of fresh weight of fruits of strawberry cultivars grown in the South of Minas Gerais region and subjected to applications of biological products.

\begin{tabular}{cccc}
\hline Cultivars & $\begin{array}{c}\text { Bacillus } \\
\text { methylotrophicus }\end{array}$ & Bacillus subtilis & Control \\
\hline Festival & $5232.86 \mathrm{aA}$ & $2089.63 \mathrm{bB}$ & $2434.53 \mathrm{bAB}$ \\
Oso Grande & $4839.73 \mathrm{aA}$ & $4409.20 \mathrm{abA}$ & $3320.30 \mathrm{bA}$ \\
Albion & $2192.23 \mathrm{aB}$ & $1964.73 \mathrm{aB}$ & $1481.80 \mathrm{aB}$ \\
Camarosa & $2157.93 \mathrm{aB}$ & $2000.43 \mathrm{aB}$ & $1624.43 \mathrm{aAB}$ \\
San Andrea & $2002.00 \mathrm{aB}$ & $1038.26 \mathrm{aB}$ & $1196.80 \mathrm{aB}$ \\
Camino Real & $1811.53 \mathrm{aB}$ & $926.23 \mathrm{aB}$ & $993.23 \mathrm{aB}$ \\
\hline CV (\%) & & $31.05 \%$ & \\
\hline
\end{tabular}

Means followed by the same uppercase letter in the column and lowercase in the row do not differ from each other by the Tukey test $(P \leq 0.05)$. Source: The authors.

Among the tested cultivars, Festival and Oso Grande were the most productive regardless of the treatment. They also were the only ones to present significant differences in relation to the application of biological products. For Festival cultivar, the application of a product based on $B$. methylotrophicus caused an increase in production of around 214.9 and $250.4 \%$ in relation to the use of a product based on $B$. subtilis and the non application of any product, respectively. In the case of the cultivar Oso Grande, it was observed that the use of the two tested products favored an increase in the production of the plants by up to $145.7 \%$.

Due to its high production already observed in many areas of the producing regions of the state of Minas Gerais, the cultivar Oso Grande has been the most cultivated by strawberry producers for some years, reaching around $90 \%$ of utilization in the planting areas. The higher production observed in this experiment for this cultivar may be due to the particularities of its fruits, which are normally heavier in relation to other cultivars (PEREIRA et al., 2013). Probably, Oso Grande and Festival present higher genetic performance in relation to production, a characteristic that was optimized with the application of the biological products applied in this study.

The Bacillus genus has been the focus of numerous researches due to its actions such as biological control, pathogenicity and plant bio stimulant, being present in more than $50 \%$ of the formulations of commercial biological products (CAWOY et al., 2011). These bacteria act on several fronts, such as the production of plant regulators (auxin, cytokinin, gibberellin) and increased availability of nutrients such as nitrogen and phosphorus. Consequently, plants have superior sanity with improved growth and development (GUPTA et al., 2015; XU et al., 2016). Hernández et al. (2018) reported greater growth and induction of systemic resistance in strawberry cv. Aromas when the plants received application of B. methylotrophicus. The application of $B$. methylotrophicus also promoted greater growth of lettuce plants (RADHAKRISHNAN; LEE, 2016).

For the other cultivars, the use of the products did not result in a significant increase in production. Possibly, the other cultivars were less adapted to the region and/or had lower genetic performance in relation to production, so that the application of Bacillus-based products could not contribute significantly to the increase in fruit mass production. Oliveira et al. (2017) also found no significant difference for the production and productivity components of common bean plants that received application of a $B$. subtilis-based product.

Regarding the number of fruits, significance was observed only for the isolated factors (biological products and cultivars). The application of the product based on $B$. methylotrophicus provided an increase of $35 \%$ and $45 \%$ in relation to the use of $B$. subtilis and the non-application of products, respectively (Figure 1). 
Figure 1. Number of strawberry fruits obtained from plants submitted to the application of biological products in the South of Minas Gerais.

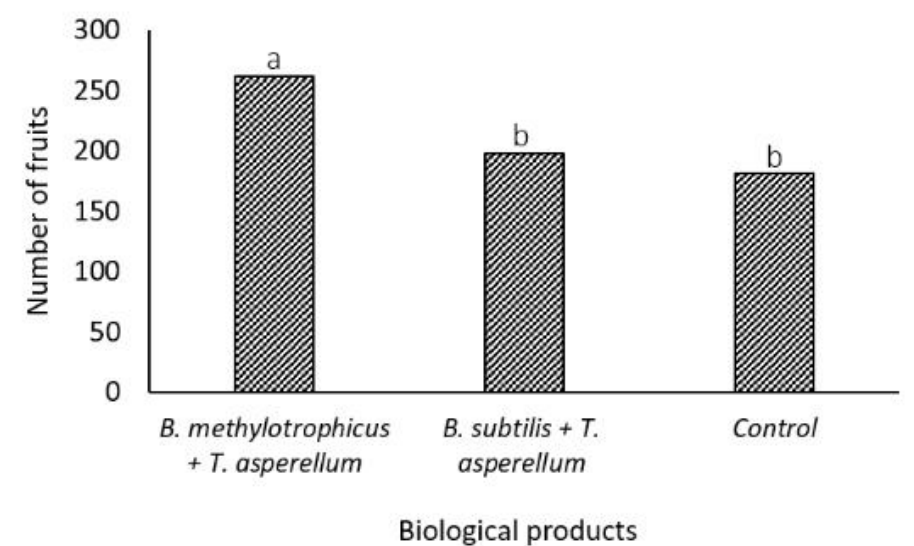

Means followed by the same do not differ from each other by the Tukey test $(P \leq 0.05)$.

Source: The authors.

For the cultivar factor, it was observed that the greatest number of fruits was obtained using the cultivars Festival and Oso Grande, already considered the most commercially productive (Figure 2).

Figure 2. Number of fruits obtained from plants of different strawberry cultivars in the South of Minas Gerais.

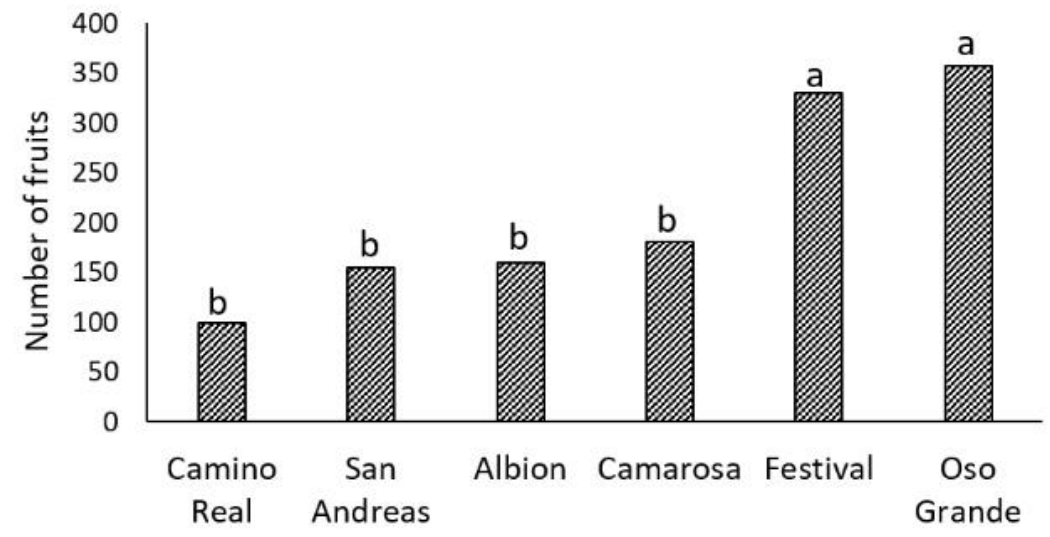

Cultivars

Means followed by the same letter do not differ from each other by the Tukey test $(P \leq 0.05)$.

Source: The authors.

These isolated results for the cultivar factor were already expected, since Oso Grande and Festival are cultivars highly adapted to the growing region, presenting a greater number of fruits in commercial plantations, as already reported by other authors (PEREIRA et al., 2013; PÁDUA et al., 2015).

Finally, the results of this work show that the use of Bacillus-based products, specifically $B$. methylotrophicus, is an alternative to enhance the strawberry production. The application of rhizobacteria, for example Bacillus, as bio fertilizers agents is part of sustainable agriculture practices and is being increasingly researched today. This class of bacteria is considered a new environmentally-friendly technology (BABALOLA, 2010). Many works in this line have already been performed, so that the existing commercial formulations do not reflect everything that has already been researched (ALOO et al., 2019). More studies should be done to further elucidate the modes of action of these microorganisms so that they can be used in a practical way in the field. 


\section{Conclusions}

The application of products based on $B$. methylotrophicus is recommended for strawberry plants cv. Festival and Oso Grande aiming to increase production and number of fruits in crops in the South of Minas Gerais.

\section{Acknowledgements}

The authors would like to thank the Lallemand Plant Care for part of financial support and donation of biological products and to the agricultural technician Heliton Moreno Mendonça for participating in the experiment evaluations.

\section{References}

ALOO, B. N.; MAKUMBA, B. A.; MBEGA, E. R. The potential of Bacilli rhizobacteria for sustainable crop production and environmental sustainability. Microbiological Research, v.219, p.26-39, 2019.2 DOI: https://doi.org/10.1016/j.micres.2018.10.011

BABALOLA, O. O. Beneficial bacteria of agricultural importance. Biotechnology Letters, v.32, p.1559-1570, $2010 . \quad$ DOI: https://doi.org/10.1007/s10529-010-0347-0

BRAGA JUNIOR, G. M.; CHAGAS JUNIOR, A. F.; CHAGAS, L. F. B.; FILHO, M. R. C.; MILLER, L. O.; SANTOS, G. R. Controle biológico de fitopatógenos por Bacillus subtilis in vitro. Biota Amazônia, v. 7, n. 3, p. 45-51, 2017.

CAPRONI, C. M.; SOUZA, A. G.; FERREIRA, S.; FAQUIN, V.; SOUZA, A. A. Produção sustentável de morangueiro. Revista Agrogeoambiental, v.5, n.3, p.91-98. DOI: https://doi.org/10.18406/23161817v5n32013545

CAWOY, H.; BETTIOL, W.; FICKERS, P.; ONGENA, M. Bacillus-based biological control of plant diseases. In: STOYTCHEVA, M. Pesticides in the modern world - Pesticides use and management. Rijeka: InTech, 2011. p.273-302. DOI: https://doi.org/10.5772/17184

CERUTTI, P. H.; SANTOS, M. Desafios do cultivo de morangueiro no Brasil. Revista TécnicoCientífico, v.20, n.2, p.236-252, 2018. DOI: https://doi.org/10.30945/rcr-v20i2.305
CHOUDHARY, D. K.; JOHRI, B. N. Interactions of Bacillus spp. and plants - with special reference to induced systemic resistance (ISR). Microbiological Research, v.164, n.5, p.493-513, 2009.

DOI:

https://doi.org/10.1016/j.micres.2008.08.007

DADRASNIA, A.; USMAN, M. M.; OMAR, R.; ISMAIL, S.; ABDULLAH, R. Potential use of Bacillus genus to control of banana diseases: approaches toward high yield production and sustainable management. Journal of King Saud University Science, v.32, n.4, p.2336-2342, 2020. DOI: https://doi.org/10.1016/j.jksus.2020.03.011

DAROLT, M. R. Morango orgânico: opção sustentável para o setor. Revista Campo \& Negócios, v.34, p.58-61, 2008.

FERREIRA, D. F. SISVAR: um sistema computacional de análise estatística. Ciência \& Agrotecnologia, v.35, n.6, p.1039-1042, 2011. DOI: $\quad$ https://doi.org/10.1590/S141370542011000600001

FERREIRA, T. C. Biocontrole de patógenos de solo e promoção de crescimento vegetal promovidos por Bacillus spp. em milho. Journal of Biology \& Pharmacy and Agricultural Management, v.15, n.4, p.337-356, 2019.

GONÇALVES, M. A.; ANTUNES, L. E. C. Mudas sadias: o início do sucesso no cultivo de morango. Campo \& Negócios - Hortifruti, n.156, p.114-115, 2018.

GUPTA, G.; PARIHAR, S. S.; AHIRWAR, N. K.; SNENI, S. K.; SINGH, V. Plant growth promoting Rhizobacteria (PGPR): Current and future prospects for development of sustainable agriculture. Journal of Microbiology and Biochemistry, v.7, p.96-102, $2015 . \quad$ DOI: https://doi.org/10.4172/1948-5948.1000188

HERNÁNDEZ, A. V.; GARCIGLIA, R. S.; CANTERO, E. V.; ORDORICA, A. R.; GARCÍA, A. H.; JUÁREZ, P. G.; RODRÍGUEZ, L. M. Bacillus methylotrophicus M496 stimulates the growth of strawberry (Fragariaxananassa 'Aromas') plants in vitro and slows Botrytis cinerea infection by two different methods of interaction. Journal of Plant Growth Regulation, v.38, p.765-777, 2018. DOI: https://doi.org/10.1007/s00344-018-9888-6 
LANNA FILHO, R.; FERRO, H. M.; PINHO, R. S. C. Controle biológico mediado por Bacillus subtilis. Revista Trópica - Ciências Agrárias e Biológicas, v.4, n.2, p.12-20, 2010. DOI: http://dx.doi.org/10.0000/rtcab.v4i2.145.

OLIVEIRA, G. R. F.; SILVA, M. S.; PROENÇA, S. L.; BOSSOLANI, J. W.; CAMARGO, J. A.; FRANCO, F. S.; SÁ, M. E. Influência do Bacillus subtilis no controle biológico de nematoides e aspectos produtivos do feijoeiro. Brazilian Journal of Biosystems Engineering, v.11, n.1, p.47-58, 2017. DOI:

https://doi.org/10.18011/bioeng2017v11n1p47$\underline{58}$.

PALOMBINI, M. C. Qual o panorama da produção de morango no Brasil? Revista Campo e Negócios Online. Disponível em: https://revistacampoenegocios.com.br/qual-opanorama-da-producao-de-morango-no-brasil/. Acesso em: 03 de junho de 2020.

PÁDUA, J. G.; ROCHA, L. C. D.; GONÇALVES, E. D.; ARAÚJO, T. H.; CARMO, E. L.; COSTA, R. Comportamento de cultivares de morangueiro em Maria da Fé e Inconfidentes, sul de Minas Gerais. Revista Agrogeoambiental, v.7, n.2, p.6979, 2015. DOI: http://dx.doi.org/10.18406/23161817v7n22015543

PEREIRA, W. R.; SOUZA, R. J.; YURI, J. E.; FERREIRA, S. Produtividade de cultivares de morangueiro, submetidas a diferentes épocas de plantio. Horticultura Brasileira, v. 31, p. 500-503, 2013. DOI: https://doi.org/10.1590/S0102$\underline{05362013000300026}$

RADHAKRISHNAN, R.; LEE, I. J. Gibberellins producing Bacillus methylotrophicus KE2 supports plant growth and enhances nutritional metabolites and food values of lettuce. Plant Physiology and Biochemistry, v.109, p.181-189, 2016.

DOI:

https://doi.org/10.1016/i.plaphy.2016.09.018

SOUSA, I. M.; NASCENTE, A. S.; FILIPPI, M. C. C. Bactérias promotoras do crescimento radicular em plântulas de dois cultivares de arroz irrigado por inundação. Colloquium Agrariae, v.15, n.1, p.140-145, 2019.2 DOI: https://doi.org/10.5747/ca.2019.v15.n1.a293.
TONIN, J.; MACHADO, J. T. M.; SOBUCKI, L.; BENATI, J. A.; ROHRIG, B.; SCHNEIDER, E. P. Controle de plantas daninhas e aspectos produtivos de morangueiro sob diferentes coberturas do solo. Revista de Ciências Agroveterinárias, v.16, n.1, p.48-53, 2017. DOI: https://doi.org/10.5965/223811711612017048.

WIDNYANA, K.; SUKERTA, M.; WISWASTA, G. N. A.; LIMANTARA, L. M. The role of rizobacteria Pseudomonas alcaligenes, Bacillus sp. and mycorrehizal fungi in growth and yield of tomato plants. International Journal of GEOMATE, v.17, n.61, p.174-180, $2019 . \quad$ DOI: https://doi.org/10.21660/2019.61.49587.

$X U$, S. J.; PARK, D. H.; KIM, J. Y.; KIM, B. S. Biological control of gray mold and growth promotion of tomato using Bacillus spp. isolated from soil. Tropical Plant Pathology, v.41, p.169176, 2016. DOI: https://doi.org/10.1007/s40858$\underline{016-0082-8 .}$. 